\title{
Faba Bean Gall (Olpidium viciae K.) as a Priority Biosecurity Threat for Producing Faba Bean in Ethiopia: Current Status and Future Perspectives
}

\author{
Birhanu Kahsay Meresa (D) and Hailay Mehari Gebremedhin \\ Department of Biotechnology, Mekelle University, Mekelle, Tigray, Ethiopia \\ Correspondence should be addressed to Birhanu Kahsay Meresa; birhanukahsay@gmail.com
}

Received 24 February 2020; Revised 1 June 2020; Accepted 3 June 2020; Published 18 August 2020

Academic Editor: Maria Serrano

Copyright (c) 2020 Birhanu Kahsay Meresa and Hailay Mehari Gebremedhin. This is an open access article distributed under the Creative Commons Attribution License, which permits unrestricted use, distribution, and reproduction in any medium, provided the original work is properly cited.

\begin{abstract}
The diploid cool-season legume species, faba bean (Vicia faba L.), is one of the vital pulses for the people in the world as it maintains the sustainability of agriculture and provides nutrient-rich grains. Biotic and abiotic stresses are, however, challenging the faba bean production in many countries. The foliar diseases of faba bean are among the major constraints for the production and productivity of faba bean. Recently, a new foliar disease "Faba bean gall" caused by plant debris and soil-borne pathogen (Olpidium viciae K.) is rapidly spreading and causing high yield losses in Ethiopia. This review paper presents the distribution, impact, epidemiology, and biology of faba bean gall pathogen and principally illustrates how the application and investigation of the various diseases' management approaches such as avoiding crop residues, crop rotation, intercropping, use of elicitors to induce host resistance, use of resistant genotypes, bioagents, compost teas, plant extracts, and lastly use of chemical fungicides could be important to control the faba bean gall disease underlying in faba bean.
\end{abstract}

\section{Introduction}

Faba bean (Vicia faba L.) is one of the oldest crops domesticated in the Fertile Crescent and is now cultivated worldwide [1]. It is a diploid $(2 \mathrm{n}=2 x=12)$ cool-season legume species [2] having large genome size $(\sim 13 \mathrm{~Gb})$ with $85 \%$ of repeated sequences [3]. It is mainly grown in high rainfall and irrigated areas of the world $[4,5]$. Faba bean is of one the most important pulse crops as it has high yield potential and protein-rich grains and hence serves as human consumption and animal feed. Faba bean also plays pivotal roles in sustaining agricultural production and productivity through nitrogen fixation and crop ration $[1,2,6]$.

Ethiopia is one of the largest faba bean producers ranked second after China. Australia, UK, and Germany are also among the largest faba bean producers after Ethiopia [7]. In highland areas of Ethiopia, faba bean is a major staple food crop among pulses [8] and the most vital legume crop after the staple cereals [9]. It is a dominant legume crop in area coverage and production than the other pulses in the country. In terms of the average yield, however, faba bean $\left(2.32 \mathrm{t} \cdot \mathrm{ha}^{-1}\right)$ is second after soya bean $\left(2.50 \mathrm{t} \cdot \mathrm{ha}^{-1}\right)$ followed by chickpea $\left(2.27 \mathrm{t} \cdot \mathrm{ha}^{-1}\right)$ and grass pea $\left(2.21 \mathrm{t} \cdot \mathrm{ha}^{-1}\right)$. Despite its instability due to biotic and abiotic stresses, the faba bean production in Ethiopia has shown an increment that ranges from $0.29 \mathrm{t} \cdot \mathrm{ha}^{-1}$ to $2.32 \mathrm{t} \cdot \mathrm{ha}^{-1}$ over $2012 / 13$ and $2017 / 18$ estimates [10].

Faba bean production and productivity is adversely affected by biotic pressures (insect-pests, parasitic weeds, and mainly foliar diseases), abiotic pressures (drought, heat, and acidity), and poor agronomic practices causing a steady reduction in many countries. Among the fungal diseases, chocolate spot (Botrytis fabae), root rots (Fusarium spp.), rust (Uromyces viciae-fabae), downy mildew (Peronospora viciae), and Ascochyta blight (Ascochyta fabae) are the most destructive constraints to the crop $[1,5,11,12]$. Recently, a newly spreading disease, "faba bean gall" (FBG), caused by a soil-borne pathogen (Olpidium viciae), is considered as a 
major challenge for the crop in Ethiopia, mainly in the regions of Tigray, Amhara, and some parts of Oromia $[11,13,14]$, which is causing yield losses as high as $100 \%$ $[15,16]$. Thus, the pathogen is now becoming a priority biosecurity threat for the production of the crop in the country [17].

The pathogen was reported for the first time as a new species in 1912 in Japan by Shunsuke Kusano. Thereafter, the incidence of broad bean-blister disease in China caused by the same pathogen has been described [18]. Recently, the disease is repeatedly reported in Ethiopia since 2010/11 major crop season $[11,13,15,19]$. Due to its infrequent occurrence and geographical limitation, it did not get worldwide attention so far which resulted in scant scientific information of this economically important phytopathogen. Microscopic examinations of the isolates of the pathogen from Ethiopia have shown similarities with the previous descriptions made for the pathogen [20]. Zhesheng et al. [18] made the first microscopic analysis of the phytopathogen. The pathogen is parasitic in the epidermal cells of faba bean leaves, stalk, and to some extent on petiole but not the fruits. Diseased plant leaves develop small tumor-like spots at the initial stage (unique feature) and soon fused to form large gall resulting in abnormal growth of leaves followed by necrosis [20-22].

In this review, an overview of research directions that are essential in order to deliver effective disease management approaches underlying FBG disease of faba bean are presented. The epidemiology of the disease in Ethiopia, the life cycle of the pathogen, and the current knowledge of the biology of the pathogen are first explained. Then, the use of crop rotation, intercropping, plant extracts, bioagents, compost tea, varietal resistance, elicitors-induced host resistance, and synthetic agrochemicals as effective control strategies to suppress the FBG disease pathogen are illustrated. Concurrently, it illuminated how the advent of molecular markers, next-generation sequencing technologies, analysis of the molecular nature of the pathogen-host interaction, and race development could play key roles in advancing the knowledge of this plant pathogen infection process and disease management approaches to enhance yield. The main aim of this review is to provide an overview of research directions, which ultimately may help to tackle the FBG disease in Ethiopia, thus enhancing the faba bean production and productivity.

\section{Symptoms}

Symptoms of the disease are mostly appearing at the leaf and stalk of the plant and to some extent on the petiole, but not on the fruits [20]. Disease symptoms on plants usually appear 13-18 days after infection [18]. At its initial appearance, round bulge spots are observed at one side of the leaves and later grown into a small tumor-like gall (Figure 1(a)). Soon the galls alter to brownish and spread to whole leaves and stalk. The individual galls are able to fuse and form huge gall with irregular shapes resulting in abnormal growth of leaves. Later, the gall turns to black or brown, the tissues decay, and galls break to cause necrosis.
Under severe infection, there is complete contraction and dysmorphosis of the leaves, and the plant becomes small with a few pods $[17,20]$. The development of small tumorlike spots with a slightly rough surface at the initial stage is a unique feature of the disease and an important basis for the diagnosis of the disease [20].

\section{Biology and Ecology of Olpidium viciae}

3.1. Life History of the Pathogen. A farm with remains of the last season infected faba bean is a primary source of dormant spores (cysts) serving as inoculum for the new season. When an optimum temperature and humidity coexist, these dormant spores germinate and release a motile spore (zoospore) through their spore tube. Basically the zoospore is unicellular with rounded protoplast and has a single flagellum for motility [20, 21].

Before infestation, zoospores are conjugated to form a zygote with two cilia. Then these zygotes are responsible to penetrate and parasitize the epidermal cells of the leaf, stalk, and petioles of the young seedlings of faba bean. Once the zygote is inside the host cell, it forms a thin-walled zoosporangium to develop the disease. The mature zoosporangia constantly release zoospores to initiate a highly repeated second infection $[20,21]$. Under the presence of rain, wind, and constant release of zoospores, the disease is dispersed quickly in the field (Figure 1(b)) and reached its peak outbreak around flowering and pod formation stages and then stopped gradually [20]. To complete the disease cycle, binucleate dormant sporangia with multiple short spore tubes are formed in the late growth stage of faba bean $[20,21]$. The cysts can exist in the soil from one up to two years, and dormant spores found $3.5 \mathrm{~cm}$ deep in the soil have higher infection rates than those placed at deeper or shallower [21].

3.2. Pathogen Taxonomy and Nomenclature. The scientific classification of the pathogen is under kingdom: Fungi, phylum: Chytridiomycota, order: Chytridiales, family: Olpidiaceae, genus: Olpidium, and species: viciae. Most species of the genus Olpidium infect higher plants, principally crops, and most of them are considered as fungal vectors. For example, Olpidium brassicae transmits lettuce big vein virus and big vein associated varicosavirus [23]; tobacco stunt virus [24]; O. virulentus is a vector for Blueberry mosaic associated virus (BlMaV) for exchanging in between blueberries [25]; and the Olive mild mosaic virus was transmitted by $O$. virulentus among cabbage plants [26]. However, virus transmission via $O$. viciae is unclear yet. Rather, O. viciae is exceptional in causing the FBG disease in faba bean. The pathogen responsible for FBG disease in faba bean got its name Olpidium viciae Kusano after it was published as a new species in 1912 by Shunsuke Kusano.

3.3. Pathogen Hosts. According to the investigation of Zhesheng et al. [18] on O. viciae host range by artificial inoculation, in addition to faba bean, the pathogen can also infect pea vetch (Vicia unijuga), rape (Brassica napus), 


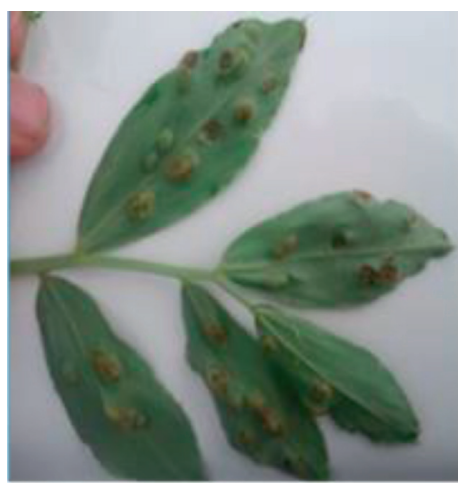

(a)

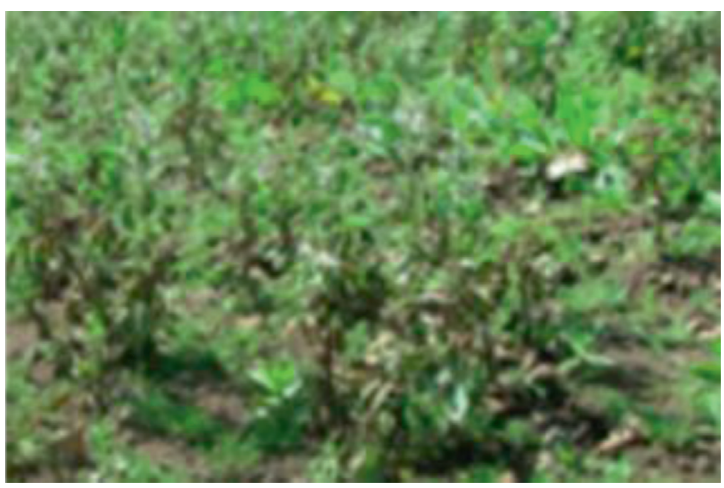

(b)

Figure 1: (a) Faba bean leaf with gall [19]. (b) Highly infested faba bean field [20].

cabbage (B. oleracea var. capitata), Chinese cabbage (B. pekinensis), radish (Raphanus sativus), cucumber (Cucumis sativus), pumpkin (Cucurbita moschata), lettuce (Lactuca sativa), spinach (Spinacia oleracea), buck-wheat (Fagopyrum esculentum), soybean (Glycine max), and kidney bean (Phaseolus vulgaris). Recently, Getaneh et al. [20] have conducted a study on an alternative host of this pathogen in other pulse crops. Thus, gall symptoms were shown on field pea, lentil, vetch, and grass pea at lower severity, of which, field pea was the highly infested crop next to the control (faba bean). This indicates that the pathogen has a potential alternative host that can be a significant source of inoculums for the susceptible crop in the next season.

3.4. Outbreak, Distribution, and Impact of the Disease in Ethiopia. In Ethiopia, the disease was reported for the first time in North Shewa Zone (Menze Mama and Mojana districts) in the 2010/11 main cropping season [19]. Subsequently, its occurrence, prevalence, and damage were reported from central and northern parts of the country which are considered as major faba bean cultivating areas $[13-16,27,28]$. Consequently, the disease is considered as a serious threat for faba bean production in the country [17].

The disease is mostly distributed in the highland areas of the country at the altitude of 1800 masl and above, which is suitable for faba bean growth $[19,20]$. It becomes more severe as the altitude increases [27]. For infection and morbidity, the temperature is also a key factor and the optimum temperature is in the range of 10 and $25^{\circ} \mathrm{C}$. The application of manure-containing residues of diseased plants is also favorable to the onset of the disease. Once the disease has gained momentum, zoospores are constantly released for the second invasion and rapidly disseminated in the field with the coexistence of rain and wind [20].

Since its first report, the disease is severely affecting faba bean production and productivity in Ethiopia. In the central and northern parts of the country, the disease incidence ranged from 0 to $100 \%$ during the 2013 main crop season [27]. Hailu et al. [27] reported that the mean disease severity was $22.2 \%, 11.3 \%$, and $7.8 \%$ in Amhara, Tigray, and Oromia regions, respectively. Therefore, the pathogen has a high potential to cause substantial $(\sim 100 \%)$ yield losses. Accordingly, the farmers are highly concerned by the consequences of the disease, and the production of the crop in Ethiopia is thus challenged [13, 27].

\section{Strategies and Future Perspectives}

Food insecurity is a worldwide primacy problem and crop failure is among the contributors. Epidemic diseases, oomycetes, insect-pests, frequent environmental fluctuations associated with climate change, etc. are among the several factors causing crop productivity reduction. The fasthuman population growth and continuous evolution of phytopathogens drive to give attention to improving the plant protection approaches. Different controlling strategies such as cultural practices (planting time, weed management style, intercropping, and crop rotation), use of resistant varieties, use of plant extracts, compost teas, bioagents, application of other biotic and abiotic inducers to elicit host immunity, and lastly application of chemicals (environmental safety must be taken into consideration) (Figure 2) have been implemented and proven successful results against enormous crop pathogens.

4.1. Cultural Practices. Deploying principles of avoiding suitable growth conditions for the phytopathogen mainly through disturbing the interactions of the pathogen with hosts and an environment that is important for disease development can be an effective practice to control FBG disease in the faba bean field. However, the effect on yield parameters should be taken into consideration.

4.1.1. Deploying Cultivar Mixtures/Multiline Cultivars. Cultivar mixtures and multilines are among the best alternative breeding strategies that enable to utilize crop diversity [29-31]. Crop diversification can allow farmers to select a strategy that both enhances resilience and offers economic advantage [32]. Wild species are more diversified in resistance genes than the domestic ones and thus evade disease outbreaks [33]. Cultivar mixtures/multiline cultivars as a strategy to diminish disease damage and increase yield 


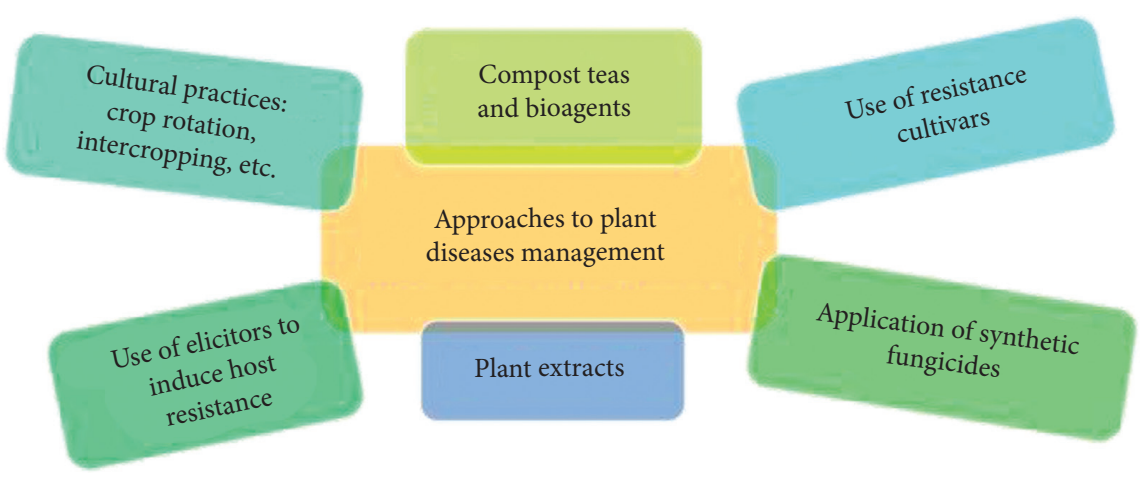

Figure 2: Possible strategies and future perspectives to control the FBG disease.

have been used in wheat [34], rice [35], faba bean [36], barley [37], and common bean [38]. Hence, disease resistance is inadequately characterized in faba bean; multilines or mixtures in faba bean have never been used to develop FBG resistance in this crop. As technologies are enabling us to advance our knowledge of genetic diversity for disease resistance, there is no reason to conclude that multilines or mixtures will not work without any proving. Therefore, studies on a mixture of FBG-resistance and susceptible genotypes for disease, restraint, and yield constancy are important.

\subsubsection{Intercropping, Crop Rotations, and Others.} Cereal/legume intercropping has a substantial and consistent effect on yield enhancement and disease incidence reduction in faba bean though it is not sufficient to provide complete disease control $[11,39,40]$. Since the cyst can exist in the soil for one or two years, crop rotation with nonhost plants mainly cereals could be effective to control the disease. Therefore, intercropping, crop rotation, and other cultural practices such as row spacing, planting time, and planting geometry should also be considered for FBG disease management.

4.2. Use of Plant Extracts, Compost Tea, and Bioagents. The application of synthetic fungicides to control cropdamaging diseases is becoming excluded due to the evolving of resistant phytopathogen strains and their economic cost and environmental risks. Utilization of biocontrol strategies (such as bioagents, compost teas, and plant extracts or their essential oils) for crop pathogens management are better options as they are effective, eco-friendly, easily available, and cheap than the synthetic fungicides [41-44].

Plants produce secondary metabolites that are rich in phenolic compounds, steroids, tannins, and alkaloids which are related to the inhibition of microorganism's growth [41]. Studies have shown that plant extracts are capable of controlling or reducing the deleterious effects of many soilborne fungal phytopathogens through inhibiting mycelium growth and spore germination [45-47]. Although Ethiopia is reported as the center of plant diversity, research on the efficacy of plant extracts to control phytopathogens is still behind. Under in vitro and greenhouse test, however, Mesfin
[48] has found satisfactory results on the efficacy of crude extracts of seven plant species (Datura stramonium, Solanum marginatum, Solanum incanum, Calpurnia aurea, Croton macrostachyus, Clematis hirsute, and C. sinensis) against $B$. fabae, a causative pathogen of chocolate leaf spot on faba bean. Similarly, improved yield, reduced disease incidence, severity, and mycelial growth were obtained from Schinus molle [46] and Phytolacca dodecandra [47] extracts sprayed on $B$. fabae infected faba bean plants under field condition. Abayhne and Chauhan [45] demonstrated that extracts from three plant species (Moringa stenopetala, D. stramonium, and Rhamnus prinoides) showed the highest activity against Phytophthora infestans, the causative agent of late blight disease of potato, under in vitro experiment. Moreover, extracts and essential oils of Eugenia caryophyllus (Spreng.) at $0.5 \%$ dilution totally inhibit the mycelial dry weight and B. fabae linear growth under the in vitro test [49]. Soliman et al. [49] have also reported that extracts of E. caryophyllus were more effective in decreasing disease severity and incidence of faba bean chocolate spot than the synthetic agrochemical (Ridomil-MZ) under field study.

The terms compost tea or liquid compost or compost extracts are commonly used to express the water-based compost preparation [42]. Based on the intent involvement or absence of air during liquid compost preparation, it can be aerated compost tea or nonaerated compost tea, respectively [43, 50]. According to various literatures, soil drenches or foliar sprays of compost tea to plants have high potential to promote plant growth and suppress different diseases, mainly the soil-borne foliar pathogens. Although fungi genera (Trichoderma and Penicillium) and viruses are involved, bacterial consortia are most frequently reported as responsible microbes for plant pathogen-suppressive effect of compost tea [42]. Among the several mechanisms involved for suppression of phytopathogens compost teas are competition, antibiosis production, hyperparasitism, induced host resistance, and failure in pathogen proliferation [51]. Under in vivo trial, aerated compost tea of cow and horse dung effectively reduced the severity of chocolate spot (B. fabae) to less than 22\%; aerated compost tea of cow dung lower the rust (Uromyces viciae-fabae) severity to $22.2 \%$, and similarly, use of aerated cow dung and nonaerated horse dung compost teas minimize the severity of Ascochyta blight (Ascochyta fabae) to below $18.5 \%$ in faba bean [52]. Twice a 
week spray of aerated compost tea with 1:8 ratio of compost to water $(\mathrm{v} / \mathrm{v})$ was effective to control powdery mildew, the important foliar disease of rose bush, caused by Sphaerotheca pannosa var. rosae [53].

Likewise, the application of fungal antagonistic (Trichoderma spp., Gliocladium virens) and bacterial antagonistic (Xanthomonas maltophilia, Flavobacterium balustinum, and Pseudomonas putida) microorganisms in combination with plant extracts or compost tea or alone as an effective biological control to limit the crop damages caused by soil-borne fungi is well documented [51]. Trichoderma spp. are mostly found in plant root ecosystems and protect plants from phytopathogens attack by various mechanisms such as inducing the host resistance, mycoparasitism, competition, and enzymes and antibiotic synthesis $[44,54]$. Use of essential oils (carnation, caraway, thyme, peppermint, and geranium) integrated with bioagent Trichoderma harzianum, resulted in pronounced protection to faba bean emerged seeds against root-rot pathogenic fungi [55]. Three times with 15-day interval foliar sprays of bioagent $T$. harzianum and antioxidants (vitamin $\mathrm{C}$, vitamin $\mathrm{E}$, selenium, minerals, and multivitamin B) reduced the faba bean chocolate spot disease incidence at a range of $66.6 \%$ to $92.2 \%$ under natural infection [56]. Local isolates of Trichoderma spp. effectively inhibited the mycelial growth of Fusarium solani, the causative agent of black root rot, under lab test, and also significantly reduced the black root rot severity on faba bean seedlings under in vivo pot experiment [57]. Similarly, Surekha et al. [58] studied the efficacy of T. viride spore suspension to control the Fusarium oxysporum and Alternaria alternate in black Gram (Vigna mungo) under greenhouse conditions. They reported that enhanced plant growth, seed germination percentage, disease resistance, and decreased lipid peroxidation were observed in T. viride-treated seeds and plants.

As explained in Section 3.1, FBG disease is a foliar disease to faba bean caused by a soil-borne fungus, and hence, it is recommended that integrated investigation and application of these biological controls (compost teas, plant extracts, and bioagents) can be effective for the management of this important disease.

\subsection{Cultivar Resistance}

4.3.1. Screening of Faba Bean Germplasm for Resistance to FBG. Genetic improvement is indispensable for better management and enhanced production of crops. Understanding the pathogenic variability, availability of possible sources of host resistance, and developing an efficient germplasm screening methods are preconditions to deliver superior resistant cultivars adapted to biotic and abiotic stresses $[59,60]$. Screening of faba bean varieties reaction under field condition against FBG has been reported in Ethiopia [22, 28]. However, an efficient selection and identification procedure of host resistance to FBG disease is not reported yet. Screening for FBG disease severity under natural infection showed a range of variations for FBG resistance in faba bean varieties, none of which were found to be free from infection. In addition, the same variety sowed on different locations showed variation in severity index $[22,28]$. This indicated that FBG severity is significantly influenced by the environment (e.g., altitude and temperature) during disease initiation and development. This could be challenging for screening and selection of FBG-resistant lines.

4.3.2. Molecular Breeding Technologies. During the last few decades, molecular markers have played an indispensable role in the development of plant breeding through markerassisted selection (MAS) and identification of economically important traits in the breeding population [61-64]. Because of their abundant availability and not being influenced by environmental factors, deployment of molecular markers would allow improved selection [65] of FBG-resistant accessions.

A number of molecular (DNA) markers which include Restriction Fragment Length Polymorphism (RFLP), Amplified Fragment Length Polymorphism (AFLP), Random Amplified Polymorphic DNA (RAPD), Simple Sequence Repeats (SSR), and Single-Nucleotide Polymorphisms (SNP) have permitted ever higher resolution and closer linkage to the genes of targets, which is useful for gene tracking throughout selection and breeding [66]. Recently, the advancement in sequencing technologies has enabled sequencing a large volume of samples [67]. This advancement provides a new opportunity in plant breeding research, including the identification of unique genes carrying an important trait through single-nucleotide polymorphisms (SNPs) and Genome-Wide Association Analysis Studies (GWAS) [68]. The country is considered as a secondary center of diversity for the species [22]. Thus, for the development of FBG-resistant varieties, there are needs for molecular as well as phenotypic screening (at the field and glasshouse) of existing germplasms and/or cultivars/local varieties. To the best of our knowledge, works on molecular markers linked to FBG resistance genes are not reported anywhere, and thus more works are expected in the near future.

Among the faba bean varieties released by EIAR, "Moti" (ILB 4432 x Kuse-2-27-33); "Gebelcho" (ILB 4726 x "Tesfa"); "Obsie" (ILB 4427 x CS20DK); and "Walki" (ILB 4615 z Bulga 70) are with good levels of disease resistance $[5,69]$. Most of these varieties including, Gebelcho, Bulga 70, Tesfa, Obsie, and Moti tested against O. viciae under natural infection showed resistance and/or moderate resistance reactions at different locations [22, 28]. However, the genetic basis of FBG resistance of these cultivars is not studied. Therefore, knowledge on candidate genes for resistance and their linkage to molecular markers would enhance the breeding efficiency and pyramiding of the genes into cultivars containing acceptable traits through marker-assisted selection (MAS) [70]. Hence, the disease is recently reported as severe in Ethiopia; genomic resource is inadequate, and consequently, breeding works for FBG resistance are not available. Thus, to deliver significant works in this causal 
agent, it is highly desirable to understand the genetic basis of FBG resistance.

4.4. Biotic and Abiotic Stresses Induced Host Defense. Exposure of plants to biotic (prior pathogen attack) and abiotic (environmental stimuli and chemicals) factors (Table 1) may enable the plant to confer systemic acquired resistance (SAR) that is the most robust and durable defense [91]. SAR plays an important role in infected plants by preparing them to confer faster and stronger resistance activation upon next infections [92]. Triggering immunity in plants using biotic and abiotic factors is along with the upregulation of pathogenesis-related genes that have valuable roles in fungal infection defense [93-95].

Cheng et al. [91] reported a nonhost resistance (NHR) due to a continuum layered defense process in faba bean in response to Puccinia striiformis $f$. sp. tritici (Pst). Pathogenassociated molecular pattern- (PAMP-) induced pathogen resistance and SAR were compromised in Arabidopsis thaliana through promoting pathogen-induced salicylic acid and pipecolic acid biosynthesis [94]. Uromyces viciae-fabae spore inoculation of lower leaves of faba bean exhibited improved rust resistance in the upper leaves and increased their photosynthesis rate [96].

Pretreatment of plants with certain chemicals can also induce systemic resistance. Prior treatment of black poplar with benzothiadiazole (BTH) and abscisic acid (ABA) resulted in enhanced defense against subsequent rust infection [77]. Exogenous sprayed 2,6-dichlorisonicotianic acid (INA) and BTH confer defense response against Rhizoctonia solani in rice [97]. Likewise, the application of $\beta$-aminobutyric acid (BABA) on Arabidopsis seedlings induced Hyaloperonospora arabidopsis resistance which is based on priming of defense-related genes [78]. It has been reported that SAR is race nonspecific and often effective against multiple biotic stresses including microbial pathogens, insects, and plant-parasitic plants [93, 98].

Moreover, induced systemic resistance (ISR), potentiated by numerous strains of nonpathogenic microorganisms such as plant growth-promoting rhizobacteria (PGPR), is another route to boost the broad-spectrum immunity in plants $[93,99,100]$. Many studies have shown the efficacy of PGPR to induce ISR such as in tomato to defend Phelipanche aegyptiaca [101] and Pseudomonas syringae [102]; cotton against Macrophomina phaseolina (Tassi) [71]; tobacco to resist Tobacco mosaic virus [103]; mung bean to protect against Macrophomina phaseolina [104]; rice against Xanthomonas campestris [105]; and tomato to defend Ralstonia solanacearum [106]. Therefore, research on the induction of disease resistance using biotic and abiotic inducers is desirable and can be regarded as one of the effective approaches to FBG management.

4.5. Understanding the Pathogen. Other bottlenecks for FBG disease management include limited knowledge of the evolutionary history, pathogenic variability, and population distribution of the pathogen. Better understanding of the pathogen is essential for an efficient resistant cultivar development [107]. Insights into the pathogenicity factors and quick and precise identification of the pathogen to the strain or species level are crucial for the development of efficient integrated disease management and disease surveillance $[108,109]$.

In phytopathogen fungi, special form (forma specialis, $\mathrm{f}$. sp.), pathotypes, and physiological races are common. A forma specialis is used to form an intraspecific taxonomic unit when morphologically similar isolates are distinguished physiologically to adapt different host genera. In pathotypes and physiological races, the isolates are morphologically identical, but show pathogenic variation which enables them to parasitize different cultivars of a single species or different species of a genus [108]. To this date, the existence of special form/pathotypes/races of O. viciae are neither confirmed nor refuted.

The study conducted by Getaneh et al. [20] and Alehegn et al. [28] demonstrated that the genotypes have shown varied severity indexes under natural infection at different locations. This tells us that the genotypes have a different level of resistance. Besides, as explained in Section 3.3, the pathogen has a wide range of hosts other than faba bean. Therefore, research on the development of physiological races and/or phenotypes of virulence, pathotypes, and possibly formae speciales of $O$. viciae could improve the existing knowledge of the pathogen as well as the plant.

Yan et al. [110] did rapid identification of internal transcribed spacer (ITS) regions of $O$. viciae by developing a polymerase chain reaction-based method. They reported that the ITS sequence of O. viciae showed $99 \%$ of homoeology with Cercospora (grey speck) pathogen. Recently, DNA barcoding and RNA-Seq-based next-generation sequencing technologies are useful for pathogenicity factors determination and rapid and accurate pathogen identification [109].

Integrative approaches such as phylogenetic characterization and genetic sequencing of isolates and determination of the genetic basis of virulence, detection of genes which are differentially expressed after infection of $O$. viciae, and profiling of the host cells, gene expression during O. viciae invasion will provide a framework to reveal the basis of pathogenicity and susceptibility in the faba bean-O. viciae interaction and thus help in the development of efficient FBG disease management strategies.

4.6. Unraveling the Molecular Dialog between Olpidium viciae and Host Interaction. The invasion and active evolving of phytopathogens hampered plant development and reproduction [111]. Since plants are sessile organisms, they have evolved complex mechanisms to overcome biotic stresses and are vital to survive under adverse growth conditions [112-114]. The plant defense mechanisms are governed by hormonal signaling, physical barriers, the production of several secondary metabolites toxic to potential phytopathogens, innate immunity system, and carbon and energy metabolisms [113, 115-117]. Plant defense mechanisms are under continuous coevolution crucial to take dominance 
TABLE 1: Some elicitor chemicals recognized as plant immunity inducer against phytopathogens.

\begin{tabular}{|c|c|c|c|}
\hline Elicitor(s) & Against phytopathogens & Protected crop & Author(s) \\
\hline \multirow{7}{*}{ BTH } & Macrophomina phaseolina (Tassi) & Cotton & {$[71]$} \\
\hline & Colletotrichum musae & Banana & {$[72]$} \\
\hline & Erwinia graminis, Puccinia recondita, and Septoria spp. & Wheat & {$[73]$} \\
\hline & Sclerotinia sclerotiorum & Sunflower & {$[74]$} \\
\hline & Uromyces appendiculatus & Bean & [75] \\
\hline & Mycosphaerella pinodes & Pea & {$[76]$} \\
\hline & Melampsora larici-populina & Black poplar & [77] \\
\hline \multirow{5}{*}{ BABA } & Hyaloperonospora arabidopsis & Arabidopsis thaliana & [78] \\
\hline & Phytophthora infestans & Potato & [79] \\
\hline & Leptosphaeria maculans & Brassica napus & {$[80]$} \\
\hline & Sclerotinia sclerotiorum & Artichoke & {$[81]$} \\
\hline & Meloidogyne graminicola & Rice & {$[82]$} \\
\hline \multirow{5}{*}{ INA } & Uromyces appendiculatus & Green bean & {$[76]$} \\
\hline & Magnaporthe grisea & Rice & [83] \\
\hline & Alternaria macrospora & Cotton & {$[84]$} \\
\hline & Xanthomonas perforans & Tomato & {$[85]$} \\
\hline & Alternaria macrospora & Cotton & {$[86]$} \\
\hline \multirow{3}{*}{ Salicylic acid } & Alternaria solani & Tomato & [87] \\
\hline & Meloidogyne incognita & Cowpea & {$[86]$} \\
\hline & Fusarium graminearum & Wheat & [87] \\
\hline \multirow{3}{*}{ Saccharin } & Blumeria graminis f. sp. tritici & Wheat & {$[88]$} \\
\hline & Phakopsora pachyrhizi & Soybean & [89] \\
\hline & Uromyces appendiculatus & Common bean & [90] \\
\hline
\end{tabular}

over their briskly evolving pathogens, which has a direct effect on plant productivity [118].

Phytopathogenic fungi release virulence effector molecules that are crucial factors to determine their pathogenicity and allow them to manipulate the host defense mechanism for a successful infection $[114,119]$. On the other side, plants secrete molecules that are involved in the recognition of these phytopathogens to induce the defense response $[118,120]$.

Gaining insights into $O$. viciae recognition capacity of faba bean, signaling mechanisms after infection, the function of host innate immunity, and virulence effector molecules of the $O$. viciae used to manipulate host defense will, therefore, underpin the search for improving the crop protection approaches and develop durable resistance to the disease in faba bean.

4.7. Chemical Application. Although the use of genetic resistance is the most effective and efficient strategy to control plant pathogens, hitherto, there are no cultivars with complete resistance to the FBG pathogen in the country. This reinforces the need to use chemicals as a short-term control strategy and thus reduce the FBG risks. Thus, searching the best fungicides for FBG management under field conditions should be carried out to evaluate its efficacy in integrated disease management strategy. Few experiments were conducted to determine the effectiveness of fungicides against FBG which are discussed hereunder.

Zhesheng et al. [18] reported that chemicals such as thiophanate-methyl, carbendazim, triadimefon, zineb, and bordeaux mixture together with three years of crop rotation showed a certain degree of efficacy. Beyene and Abiro [11] recorded minimum FBG disease score and enhanced local varieties yield from a foliar spray of triadimefon and mancozeb at seedling, flowering, and podding growth stages in a farmer's field. Similarly, Hailemariam et al. [14] obtained that triadimefon at $25 \%$ used as seed dressing significantly reduced the disease incidence, severity, and area under disease progress curve than other tested fungicides.

Bekele et al. [16] conducted a field experiment to investigate the response of three different faba bean cultivars and the efficacy of three different fungicides against FBG. And they recommended that three times spray of triadimefon fungicide (starting at the disease appearance and two times at 15-day interval) to the improved cultivar "Gora" could be effective to control this disease. Likewise, an enhanced faba bean productivity and reduced FBG disease were obtained from the application of triadimefon and a combination of metalaxyl-M and mancozeb sprayed 2-4 times compared to the other fungicides and control [11]. Wondwosen et al. [17] tested five fungicides, namely, metalaxyl-M, triadimefon, chlorothalonil, mancozeb, and fludioxonil, under natural infection for their ability to control FBG. According to them, three foliar sprays of triadimefon $250 \mathrm{~g} / \mathrm{l}$ and metalaxyl $8 \%+$ mancozeb $64 \%$ WP starting from the appearance of the disease were found effective for the management of FBG disease and were economical in terms of crop yield and net profit.

\section{Conclusion}

Faba bean is one of the dominant component crops in the Ethiopian diet. Currently, faba bean gall is among the major constraints to faba bean production in Ethiopia. Pathogens 
existing in the soil and infested plant debris are sources of inoculums for the development of the disease. The farmers plant the crop repetitively on the same farm due to its economic importance. This results in a high accumulation of the pathogen in the field, leading to high yield losses in a single cropping season. Presence of scant information about the pathogen related to its biology, ecology, epidemiology, host-pathogen interaction, and lack of awareness among farmers about the source of the pathogen and its occurrence restricted to the country might be a limiting factor for taking the required actions to inhibit/reduce the spread of O. viciae. Cultural practices, including plant density, avoiding crop residues, and evading volunteer hosts growing along with crop rotations and intercropping can help in the infestation reduction and productivity increment. Embracing of integrated pest management (IPM) strategies, including cultural practices, biological controls (bioagents, plant extracts, and compost tea), use of resistant cultivars, elicitors' induced host resistance, and, as a last alternative, use of synthetic agrochemicals should all be taken into account for preventing $O$. viciae damages. Synthetic agrochemical control should be used sparingly as it is allied with the environmental and health threats.

Application of genomics and biotechnology tools in the breeding of faba bean for $O$. viciae resistance, genome sequencing, and race development of the pathogen is far behind. Knowledge on genetics and genomics is now adequately advanced to be used in the understanding of the pathogen and its interaction with hosts. Therefore, research efforts need to be focused in the areas such as (a) genomic sequence of $O$. viciae; (b) development of a standard system for the race and pathotype identification and nomenclature; (c) revealing the genetics of racespecific and pathotype-specific susceptibility/resistance; (d) understanding the mechanisms of host resistance; (e) detection and identification of the effective source of host resistance including their incorporation in the breeding; (f) identification of pathogen virulence and variability and pathogen population distribution; (g) comparative epidemiology and prediction of faba bean gall disease; and (h) IPM of faba bean gall in faba bean comprising fungicides and other control actions.

\section{Data Availability}

The data used to support the findings of this study are available from the corresponding author upon request.

\section{Conflicts of Interest}

The authors declare that there are no conflicts of interest regarding the publication of this paper.

\section{Acknowledgments}

The authors gratefully acknowledge the Mekelle University for providing full access to an office and Internet service that helped them in critically reading the articles and developing the manuscript.

\section{References}

[1] A. M. Torres, B. Román, C. M. Avila et al., "Faba bean breeding for resistance against biotic stresses: towards application of marker technology," Euphytica, vol. 147, no. 1-2, pp. 67-80, 2006.

[2] S. Braich, S. Sudheesh, J. G. Paull, and S. Kaur, "Construction of genetic linkage map and QTLs identification for Ascochyta blight $(\mathrm{AB})$ resistance and flowering time in faba bean (Vicia faba L.)," in Proceedings of the 2016 Australian Pulse Conference, Tamworth, Australia, September 2016.

[3] R. B. Flavell, M. D. Bennett, J. B. Smith, and D. B. Smith, "Genome size and the proportion of repeated nucleotide sequence DNA in plants," Biochemical Genetics, vol. 12, no. 4, pp. 257-269, 1974.

[4] F. Maalouf, S. Ahmed, K. Shaaban et al., "New faba bean germplasm with multiple resistances to Ascochyta blight, chocolate spot and rust diseases," Euphytica, vol. 211, no. 2, pp. 157-167, 2016.

[5] F. Maalouf, J. Hu, D. M. O'Sullivan et al., "Breeding and genomics status in faba bean (Vicia faba)," Plant Breeding, vol. 138, no. 4, pp. 465-473, 2019.

[6] A. Infantino, M. Kharrat, L. Riccioni, C. J. Coyne, K. E. McPhee, and N. J. Grünwald, "Screening techniques and sources of resistance to root diseases in cool season food legumes," Euphytica, vol. 147, no. 1-2, pp. 201-221, 2006.

[7] FAOSTAT, World Statistics on Faba Bean, Food and Agriculture Organization of the United Nations, Rome, Italy, 2017, http://faostat.fao.org/.

[8] G. Agegnehu, A. Ghizaw, and W. Sinebo, "Yield performance and land-use efficiency of barley and faba bean mixed cropping in Ethiopian highlands," European Journal of Agronomy, vol. 25, no. 3, pp. 202-207, 2006.

[9] T. A. Teferi, G. B. Weldemichael, G. K. Wakeyo, and T. T. Mindaye, "Fungicidal management of the newly emerging faba bean disease "gall" (Olpidium viciae Kusano) in Tigray, Ethiopia," Crop Protection, vol. 107, pp. 19-25, 2018.

[10] CSA (Central Statistical Agency), "Report on area and production of major crops (private peasant holdings, 2017/ 18 meher season)," Statistical Bulletin, vol. 1, pp. 10-17, 2019.

[11] B. Beyene and T. Abiro, "Management of faba bean gall disease (Kormid) in north Shewa highlands, Ethiopia," Advances in Crop Science and Technology, vol. 4, no. 4, p. 225, 2016.

[12] A. Anteneh, E. Yohannes, G. Mesganaw, G. Solomon, and T. Getachew, "Survey of faba bean (Vicia faba L.) diseases in major faba bean growing districts of North Gondar," African Journal of Plant Science, vol. 12, no. 2, pp. 32-36, 2018.

[13] T. Abebe, T. Birhane, Y. Nega, and A. Workineh, "The prevalence and importance of faba bean diseases with special consideration to the newly emerging faba bean gall in Tigray, Ethiopia," Discourse Journal of Agriculture and Food Sciences, vol. 2, no. 2, pp. 33-38, 2014.

[14] B. N. Hailemariam, M. Tilahun, S. Bazie, T. Desale, and E. Abere, "Management of faba bean gall in faba bean producing area of eastern Amhara, Ethiopia," Journal of Agriculture and Environment for International Development, vol. 111, no. 2, pp. 343-350, 2017.

[15] D. Chala, N. Abraham, A. Zerihun, and T. Meseret, "Assessment of the occurrence and prevalence of faba bean gall (Olpidium viciae) in Western highlands of Oromiya, Ethiopia," Journal of Natural Sciences Research, vol. 7, no. 5, pp. 63-67, 2017. 
[16] B. Bekele, W. Dawit, B. Kassa, and T. Selvaraj, "Management of faba bean gall disease using cultivars and fungicides in north Showa zone of central Ethiopia," International Journal of Research in Agricultural Sciences, vol. 5, no. 1, pp. 6-33, 2018.

[17] W. Wondwosen, M. Dejene, N. Tadesse, and S. Ahmed, "Fungicide management of faba bean gall (Olpidium viciae) in Ethiopia," Turkish Journal of Agriculture-Food Science and Technology, vol. 7, no. 7, pp. 1075-1081, 2019.

[18] X. Zhesheng, X. Chunlan, and Z. Yonghua, "A preliminary study of blister disease of broad-bean (Olpidium viciae Kusano) and its control," Acta Psychopathological Sinica, vol. 14, no. 3, pp. 165-173, 1984.

[19] B. Bitew, "Survey and identification of new faba bean disease (Kormid) in the highlands of north Shewa, Ethiopia," Current Research Microbiology and Biotechnology, vol. 3, no. 1, pp. 561-563, 2015.

[20] G. Getaneh, E. Hailu, K. Sadessa, T. Alemu, and G. Megersa, "The causal pathogen, inoculum sources and alternative hosts studies of the newly emerged gall forming faba bean (Vicia faba) disease in Ethiopia," Advances in Crop Science and Technology, vol. 6, no. 3, p. 368, 2018.

[21] L. Li-Juan, Y. Zhao-hai, Z. Zhao-jie, X. Ming-shi, and Y. Han-ging, Faba Bean in China: State of the Art Review. Special Study Report, International Center for Agricultural Research in the Dry Areas (ICARDA), Aleppo, Syria, 1993.

[22] G. Yitayih and Y. Azmeraw, "Adaptation of faba bean varieties for yield, for yield components and against faba bean gall (Olpidium viciae Kusano) disease in south Gondar, Ethiopia," The Crop Journal, vol. 5, no. 6, pp. 560-566, 2017.

[23] J. A. Tomlison and E. M. Faithfull, "Effects of fungicides and surfactants on the zoospores of Olpidium brassicae," Annals of Applied Biology, vol. 93, no. 1, pp. 13-19, 1979.

[24] C. Hiruki, "Transmission of tobacco stunt virus by Olpidium brassicae,” Virology, vol. 25, no. 4, pp. 541-549, 1965.

[25] A. C. Shands, S. G. Crandall, and T. D. Miles, "First report of the ability of Olpidium virulentus to vector blueberry mosaic associated virus (BlMaV) on southern highbush blueberry in California," Plant Disease, vol. 101, no. 9, p. 1683, 2017.

[26] C. M. R. Varanda, S. Santos, M. I. E. Clara, and M. d. R. Félix, "Olive mild mosaic virus transmission by Olpidium virulentus," European Journal of Plant Pathology, vol. 142, no. 1, pp. 197-201, 2015.

[27] E. Hailu, G. Getaneh, T. Sefera et al., "Faba bean gall; a new threat for faba bean (Vicia faba) production in Ethiopia," Advances in Crop Science and Technology, vol. 2, no. 4, 2014.

[28] M. Alehegn, M. Tiru, and M. Taddess, "Screening of faba bean (Vicia faba) varieties against faba bean gall diseases (Olpidium viciae) in east Gojjam zone, Ethiopia," Journal of Biology, Agriculture and Healthcare, vol. 8, no. 1, pp. 50-55, 2018.

[29] H. E. Creissen, T. H. Jorgensen, and J. K. M. Brown, "Increased yield stability of field-grown winter barley (Hordeum vulgare L.) varietal mixtures through ecological processes," Crop Protection, vol. 85, pp. 1-8, 2016.

[30] P. P. Reddy, Agro-Ecological Approaches to Pest Management for Sustainable Agriculture, Springer, Singapore, 2017.

[31] E. R. Reiss and L. E. Drinkwater, "Cultivar mixtures: a metaanalysis of the effect of intraspecific diversity on crop yield," Ecological Applications, vol. 28, no. 1, pp. 62-77, 2017.

[32] B. B. Lin, "Resilience in agriculture through crop diversification: adaptive management for environmental change," Bioscience, vol. 61, no. 3, pp. 183-193, 2011.
[33] U. Ijaz, K. Adhikari, and F. L. Stoddard, "Rust resistance in faba bean (Vicia faba L.): status and strategies for improvement," Australasian Plant Pathology, vol. 47, pp. 71-81, 2017.

[34] C. Huang, Z. Sun, H. Wang, Y. Luo, and Z. Ma, "Effects of wheat cultivar mixtures on stripe rust: a meta-analysis on field trials," Crop Protection, vol. 33, pp. 52-58, 2012.

[35] L. M. Raboin, A. Ramanantsoanirina, J. Dusserre et al., "Two-component cultivar mixtures reduce rice blast epidemics in an upland agrosystem," Plant Pathology, vol. 61, no. 6, pp. 1103-1111, 2012.

[36] M. Fernández-Aparicio, M. J. Y. Shtaya, A. A. Emeran, M. B. Allagui, M. Kharrat, and D. Rubiales, "Effects of crop mixtures on chocolate spot development on faba bean grown in mediterranean climates," Crop Protection, vol. 30, no. 8, pp. 1015-1023, 2011.

[37] A. C. Newton and D. C. Guy, "Scale and spatial structure effects on the outcome of barley cultivar mixture trials for disease control," Field Crops Research, vol. 123, no. 2, pp. 74-79, 2011.

[38] F. B. S. Botelho, M. A. P. Ramalho, Â malho.ros Abreu, and H. J. A. Rosa, "Multiline as a strategy to reduce damage caused by Colletotrichum lindemuthianum in common bean," Journal of Phytopathology, vol. 159, no. 3, pp. 175-180, 2011.

[39] G. Agegnehu, A. Ghizaw, and W. Sinebo, "Yield potential and land-use efficiency of wheat and faba bean mixed intercropping," Agronomy for Sustainable Development, vol. 28 , no. 2, pp. 257-263, 2008.

[40] C. Zhang, Y. Dong, L. Tang et al., "Intercropping cereals with faba bean reduces plant disease incidence regardless of fertilizer input; a meta-analysis," European Journal of Plant Pathology, vol. 154, no. 4, pp. 931-942, 2019.

[41] K. Basaid, B. Chebli, E. H. Mayad et al., "Biological activities of essential oils and lipopeptides applied to control plant pests and diseases: a review," International Journal of Pest Management, pp. 1-23, 2020.

[42] C. Martin, "Potential of compost tea for suppressing plant diseases," CAB Review, vol. 9, no. 32, pp. 1-38, 2014.

[43] S. Scheuerell and W. Mahaffee, "Compost tea: principles and prospects for plant disease control," Compost Science \& Utilization, vol. 10, no. 4, pp. 313-338, 2002.

[44] C. R. Howell, "Mechanisms employed by Trichoderma species in the biological control of plant diseases: the history and evolution of current concepts," Plant Disease, vol. 87, no. 1, pp. 4-10, 2003.

[45] M. Abayhne and N. Chauhan, "Antifungal activity of various medicinal plants against late blight of potato from Ethiopia," Journal of Scientific Research and Reports, vol. 12, no. 5, pp. 1-9, 2016.

[46] A. Tegegn, M. C. Egigu, and B. Hundie, "Efficacy of pepper tree (Schinus molle) extracts to suppress growth of Botrytis fabae and manage chocolate spot severity on faba bean (Vicia faba) at Sinana, Bale zone, Southeastern Ethiopia," East African Journal of Sciences, vol. 10, no. 2, pp. 111-118, 2016.

[47] A. Tegegn, M. C. Egigu, and B. Hundie, "Evaluation of endod (Phytolacca dodecandra L.) extracts against Botrytis fabae, a causative agent of chocolate spot disease of Vicia faba," Cogent Food \& Agriculture, vol. 5, no. 1, 2019.

[48] R. Mesfin, "Evaluation of antifungal activity of plant extracts against chocolate spot disease (Botrytis fabae) on faba bean," M.Sc. thesis, Addis Ababa University, Addis Ababa, Ethiopia, 2010. 
[49] M. Soliman, F. F. Migahed, and A. M. Nofel, "Role of plant extract and essential oil of Eugenia caryophyllus (Spreng.) in controlling chocolate spot of Vicia faba L," Egyptian Journal of Biological Pest Control, vol. 26, no. 3, pp. 469-475, 2016.

[50] H. C. Weltzien, "Biocontrol of foliar fungal diseases with compost extracts," in Microbial Ecology of Leaves, pp. 430-450, Springer, New York, NY, USA, 1991.

[51] C. M. Mehta, U. Palni, I. H. Franke-whittle, and A. K. Sharma, "Compost: its role, mechanism and impact on reducing soil-borne plant diseases," Waste Management, vol. 34, no. 3, pp. 607-622, 2014.

[52] A. Tegegn, "Effect of aerated and non-aerated compost steepages on the severity and incidence of major fungal diseases of faba bean; Botrytis fabae, Uromyces vicia fabae and Ascochyta fabae," Plant, vol. 5, no. 6, pp. 85-92, 2017.

[53] S. Seddigh and L. Kiani, "Evaluation of different types of compost tea to control rose powdery mildew (Sphaerotheca pannosa var. rosae)," International Journal of Pest Management, vol. 64, no. 2, pp. 178-184, 2017.

[54] A. H. van Bruggen, A. Gamliel, and M. R. Finckh, "Plant disease management in organic farming systems," Pest Management Science, vol. 72, no. 1, pp. 30-44, 2016.

[55] M. Abdel-Kader, N. El-Mougy, and S. Lashin, "Essential oils and Trichoderma harzianum as an integrated control measure against faba bean root rot pathogens," Journal of Plant Protection Research, vol. 51, no. 3, pp. 306-313, 2011.

[56] N. S. El-Mougy and M. M. Abdel-Kader, "Trichoderma harzianum and some antioxidants for suppressing faba bean chocolate spot incidence under natural field infection," Australian Journal of Crop Science, vol. 12, no. 05, pp. 794-799, 2018.

[57] E. Belete, A. Ayalew, and S. Ahmed, "Evaluation of local isolates of Trichoderma spp. against black root rot (Fusarium solani) on faba bean," Journal of Plant Pathology and Microbiology, vol. 6, no. 6, p. 279, 2015.

[58] C. Surekha, N. Neelapu, G. Kamala, B. S. Prasad, and P. S. Ganesh, "Efficacy of Trichoderma viride to induce disease resistance and antioxidant responses in legume Vigna mungo infested by Fusarium oxysporum and Alternaria alternata," International Journal of Agricultural Science and Research, vol. 3, no. 2, pp. 285-294, 2013.

[59] A. Porta-Puglia, C. C. Bernier, G. J. Jellis, W. J. Kaiser, and M. V. Reddy, "Screening techniques and sources of resistance to foliar diseases caused by fungi and bacteria in cool season food legumes," Euphytica, vol. 73, no. 1-2, pp. 11-25, 1994.

[60] S. Sudheesh, M. Lombardi, A. Leonforte et al., "Consensus genetic map construction for field pea (Pisum sativum L.), trait dissection of biotic and abiotic stress tolerance and development of a diagnostic marker for the er1 powdery mildew resistance gene," Plant Molecular Biology Reporter, vol. 33, no. 5, pp. 1391-1403, 2014.

[61] B. Collard and D. Mackill, "Marker-assisted selection: an approach for precision plant breeding in the twenty-first century," Philosophical Transactions of the Royal Society B: Biological Sciences, vol. 363, no. 1491, pp. 557-572, 2008.

[62] B. Tivoli, A. Baranger, C. M. Avila et al., "Screening techniques and sources of resistance to foliar diseases caused by major necrotrophic fungi in grain legumes," Euphytica, vol. 147, no. 1-2, pp. 223-253, 2006.

[63] F. Ahmad, A. Akram, K. Farman et al., "Molecular markers and marker assisted plant breeding: current status and their applications in agricultural development," Journal of Environmental and Agricultural Sciences, vol. 11, pp. 35-50, 2017.
[64] M. A. Nadeem, M. A. Nawaz, M. Q. Shahid et al., "DNA molecular markers in plant breeding: current status and recent advancements in genomic selection and genome editing," Biotechnology \& Biotechnological Equipment, vol. 32, no. 2, pp. 261-285, 2018.

[65] B. C. Y. Collard, M. Z. Z. Jahufer, J. B. Brouwer, and E. C. K. Pang, "An introduction to markers, quantitative trait loci (QTL) mapping and marker-assisted selection for crop improvement: the basic concepts," Euphytica, vol. 142, no. 12, pp. 169-196, 2005.

[66] G. Jiang, "Molecular markers and marker-assisted breeding in plants," in Plant Breeding from Laboratories to Fields, pp. 45-83, InTechOpen, Rijeka, Croatia, 2013.

[67] O. Morozova and M. A. Marra, "Applications of nextgeneration sequencing technologies in functional genomics," Genomics, vol. 92, no. 5, pp. 255-264, 2008.

[68] H.-M. Lam, X. Xu, X. Liu et al., "Resequencing of 31 wild and cultivated soybean genomes identifies patterns of genetic diversity and selection," Nature Genetics, vol. 42, no. 12, pp. 1053-1059, 2010.

[69] M. Fouad, N. Mohammed, H. Aladdin et al., "Faba bean," in Genetic and Genomic Resources of Grain Legume Improvement, pp. 113-136, Elsevier, Amsterdam, Netherlands, 1st edition, 2013.

[70] D. K. Santra, M. Tekeoglu, M. Ratnaparkhe, W. J. Kaiser, and F. J. Muehlbauer, "Identification and mapping of QTLs conferring resistance to Ascochyta blight in chickpea," Crop Science, vol. 40, no. 6, pp. 1606-1612, 2000.

[71] H. Adrees, M. S. Haider, T. Anjum, and W. Akram, "Inducing systemic resistance in cotton plants against charcoal root rot pathogen using indigenous rhizospheric bacterial strains and chemical elicitors," Crop Protection, vol. 115, pp. 75-83, 2019.

[72] X. Zhu, H. Lin, Z. Si, Y. Xia, W. Chen, and X. Li, "Benzothiadiazole-mediated induced resistance to Colletotrichum musae and delayed ripening of harvested banana fruit," Journal of Agricultural and Food Chemistry, vol. 64, no. 7, pp. 1494-1502, 2016.

[73] J. Görlach, S. Volrath, G. Knauf-Beiter et al., "Benzothiadiazole, a novel class of inducers of systemic acquired resistance, activates gene expression and disease resistance in wheat," The Plant Cell, vol. 8, no. 4, pp. 629-643, 1996.

[74] R. Bán, G. Baglyas, F. Virányi et al., "The chemical inducer, BTH (benzothiadiazole) and root colonization by mycorrhizal fungi (glomus spp.) trigger resistance against white rot (Sclerotinia sclerotiorum) in sunflower," Acta Biologica Hungarica, vol. 68, no. 1, pp. 50-59, 2017.

[75] M. Iriti and F. Faoro, "Benzothiadiazole (BTH) induces celldeath independent resistance in Phaseolus vulgaris against Uromyces appendiculatus," Journal of Phytopathology, vol. 151, no. 3, pp. 171-180, 2003.

[76] E. K. Dann and B. J. Deverall, "2,6-dichloro-isonicotinic acid (INA) induces resistance in green beans to the rust pathogen, Uromyces appendiculatus, under field conditions," Australasian Plant Pathology, vol. 25, no. 3, pp. 199-204, 1996.

[77] C. Ullah, C. J. Tsai, S. B. Unsicker et al., "Salicylic acid activates poplar defense against the biotrophic rust fungus Melampsora larici-populina via increased biosynthesis of catechin and proanthocyanidins," New Phytologist, vol. 221, no. 2, pp. 960-975, 2019.

[78] S. Van der Ent, M. Van Hulten, M. J. Pozo et al., "Priming of plant innate immunity by rhizobacteria and $\beta$-aminobutyric acid: differences and similarities in regulation," New Phytologist, vol. 183, no. 2, pp. 419-431, 2009. 
[79] L. Eschen-lippold, S. Altmann, and S. Rosahl, "Dl- $\beta$-aminobutyric acid-induced resistance of potato against Phytophthora infestans requires salicylic acid but not oxylipins," Molecular Plant-Microbe Interactions, vol. 23, no. 5, pp. 585-592, 2010.

[80] V. Šašek, M. Nováková, P. I. Dobrev, O. Valentová, and L. Burketová, " $\beta$-aminobutyric acid protects Brassica napus plants from infection by Leptosphaeria maculans. Resistance induction or a direct antifungal effect?" European Journal of Plant Pathology, vol. 133, no. 1, pp. 279-289, 2012.

[81] E. Marcucci, M. P. Aleandri, G. Chilosi, and P. Magro, "Induced resistance by $\beta$-aminobutyric acid in artichoke against white mould caused by Sclerotinia sclerotiorum," Journal of Phytopathology, vol. 158, no. 10, pp. 659-667, 2010.

[82] H. Ji, T. Kyndt, W. He, B. Vanholme, and G. Gheysen, " $\beta$-aminobutyric acid-induced resistance against root-knot nematodes in rice is based on increased basal defence," Molecular Plant-Microbe Interactions, vol. 13, no. 9, pp. 1-53, 2015.

[83] P. Schweizer, A. Buchala, and J. P. Métraux, "Gene-expression patterns and levels of jasmonic acid in rice treated with the resistance inducer 2,6-dichloroisonicotinic acid," Plant Physiology, vol. 115, no. 1, pp. 61-70, 1997.

[84] E. S. Colson-Hanks and B. J. Deverall, "Effect of 2,6dichloroisonicotinic acid, its formulation materials and benzothiadiazole on systemic resistance to alternaria leaf spot in cotton," Plant Pathology, vol. 49, no. 2, pp. 171-178, 2000.

[85] S. Chandrashekar and S. Umesha, "2,6-dichloroisonicotinic acid enhances the expression of defense genes in tomato seedlings against Xanthomonas perforans," Physiological and Molecular Plant Pathology, vol. 86, pp. 49-56, 2014.

[86] P. Brock, J. Inwood, and B. Deverall, "Systemic induced resistance to alternaria macrospora in cotton (Gossypium hirsutum)," Australasian Plant Pathology, vol. 23, no. 3, pp. 81-85, 1994.

[87] M. E. Spletzer and A. J. Enyedi, "Salicylic acid induces resistance to Alternaria solani in hydroponically grown tomato," Phytopathology, vol. 89, no. 9, pp. 722-727, 1999.

[88] B. Nandi, N. C. Sukul, N. Banerjee et al., "Salicylic acid enhances resistance in cowpea against Meloidogyne incognita," Phytopathologia Mediterranea, vol. 41, no. 1, pp. 39-44, 2002.

[89] R. Makandar, V. J. Nalam, H. Lee, H. N. Trick, Y. Dong, and J. Shah, "Salicylic acid regulates basal resistance to fusarium head blight in wheat," Molecular Plant-Microbe Interactions, vol. 25, no. 3, pp. 431-439, 2012.

[90] L. T. Phuong, L. Zhao, A. N. Fitrianti et al., "The plant activator saccharin induces resistance to wheat powdery mildew by activating multiple defense-related genes," Journal of General Plant Pathology, vol. 86, pp. 107-113, 2019.

[91] Y. Cheng, H. Zhang, J. Yao et al., "Characterization of nonhost resistance in broad bean to the wheat stripe rust pathogen,” BMC Plant Biology, vol. 12, no. 1, p. 96, 2012.

[92] T. Guerra, S. Schilling, K. Hake et al., "Calcium-dependent protein kinase 5 links calcium signaling with N-hydroxy-lpipecolic acid- and SARD1-dependent immune memory in systemic acquired resistance," New Phytologist, vol. 4, 2020.

[93] M. R. Roberts and J. E. Taylor, "Exploiting plant induced resistance as a route to sustainable crop protection," in Plant Pathogen Resistance Biotechnology, pp. 319-328, John Wiley \& Sons, Hoboken, NJ, USA, 1st edition, 2016.
[94] T. Sun, L. Busta, Q. Zhang, P. Ding, R. Jetter, and Y. Zhang, "TGACG-binding factor 1 (TGA1) and TGA4 regulate salicylic acid and pipecolic acid biosynthesis by modulating the expression of systenic acquired resistance deficient 1 (SARD1) and calmodulin- binding protein $60 \mathrm{~g}$ (CBP60g)," New Phytologist, vol. 217, no. 1, pp. 344-354, 2018.

[95] G. Z. Han, "Origin and evolution of the plant immune system," New Phytologist, vol. 222, no. 1, pp. 70-83, 2019.

[96] D. C. Murray and D. R. Walters, "Increased photosynthesis and resistance to rust infection in upper, uninfected leaves of rusted broad bean (Vicia faba L.)," New Phytologist, vol. 120, no. 2, pp. 235-242, 1992.

[97] Y. Kouzai, M. Kimura, M. Watanabe et al., "Salicylic aciddependent immunity contributes to resistance against Rhizoctonia solani, a necrotrophic fungal agent of sheath blight, in rice and Brachypodium distachyon," New Phytologist, vol. 217, no. 2, pp. 771-783, 2018.

[98] G. J. Beckers and U. Conrath, "Priming for stress resistance: from the lab to the field," Current Opinion in Plant Biology, vol. 10, no. 4, pp. 425-431, 2007.

[99] G. E. Vallad and R. M. Goodman, "Systemic acquired resistance and induced systemic resistance in conventional agriculture," Crop Science, vol. 44, no. 6, pp. 1920-1934, 2004.

[100] M. C. Enebe and O. O. Babalola, "The impact of microbes in the orchestration of plants' resistance to biotic stress: a disease management approach," Applied Microbiology and Biotechnology, vol. 103, no. 1, pp. 9-25, 2019.

[101] S. Borzouei, R. Sharifi, and N. Moarrefzadeh, "Induction of systemic resistance in tomato against broomrape (Phelipanche aegyptiaca)," Journal of Phytopathology, vol. 167, no. 10, pp. 567-575, 2019.

[102] C.-M. Ryu, C.-H. Hu, M. S. Reddy, and J. W. Kloepper, "Different signaling pathways of induced resistance by rhizobacteria in Arabidopsis thaliana against two pathovars of Pseudomonas syringae," New Phytologist, vol. 160, no. 2, pp. 413-420, 2003.

[103] N. Wang, M. Liu, L. Guo, X. Yang, and D. Qiu, “A novel protein elicitor (PeBA1) from Bacillus amyloliquefaciens NC6 induces systemic resistance in tobacco," International Journal of Biological Sciences, vol. 12, no. 6, pp. 757-767, 2016.

[104] C. K. Sharma, V. K. Vishnoi, R. C. Dubey, and D. K. Maheshwari, "A twin rhizospheric bacterial consortium induces systemic resistance to a phytopathogen Macrophomina phaseolina in mung bean," Rhizosphere, vol. 5, pp. 71-75, 2018.

[105] J. A. Lucas, J. García-Cristobal, A. Bonilla, B. Ramos, and J. Gutierrez-Mañero, "Beneficial rhizobacteria from rice rhizosphere confers high protection against biotic and abiotic stress inducing systemic resistance in rice seedlings," Plant Physiology and Biochemistry, vol. 82, pp. 44-53, 2014.

[106] C. Li, W. Hu, B. Pan et al., "Rhizobacterium bacillus amyloliquefaciens strain SQRT3-mediated induced systemic resistance controls bacterial wilt of tomato," Pedosphere, vol. 27, no. 6, pp. 1135-1146, 2017.

[107] P. Srivastava, S. George, J. J. Marois, D. L. Wright, and D. R. Walker, "Saccharin-induced systemic acquired resistance against rust (Phakopsora pachyrhizi) infection in soybean: effects on growth and development," Crop Protection, vol. 30, no. 6, pp. 726-732, 2011.

[108] M. M. Jiménez-Gasco, J. A. Navas-Cortés, and R. M. Jiménez-Díaz, "The Fusarium oxysporum f. sp. ciceris/ Cicer arietinum pathosystem: a case study of the evolution of 
plant-pathogenic fungi into races and pathotypes," International Microbiology, vol. 7, no. 2, pp. 95-104, 2004.

[109] S. Aslam, A. Tahir, M. F. Aslam, M. W. Alam, A. A. Shedayi, and S. Sadia, "Recent advances in molecular techniques for the identification of phytopathogenic fungi-a mini review," Journal of Plant Interactions, vol. 12, no. 1, pp. 493-504, 2017.

[110] J. M. Yan, X. H. Shi, M. Mei, H. B. Dai, and H. Z. Ye, "Amplifying and sequencing analysis the internal transcribed spacer (ITS) regions of Olpidium viciae Kusano's ribosomal DNA in broad bean," Advanced Materials Research, vol. 271-273, pp. 507-513, 2011.

[111] J. D. Jones and J. L. Dangl, "The plant immune system," Nature, vol. 444, no. 16, pp. 323-329, 2006.

[112] F. Y. Cao, K. Yoshioka, and D. Desveaux, "The roles of ABA in plant-pathogen interactions," Journal of Plant Research, vol. 124, no. 4, pp. 489-499, 2011.

[113] L. A. Du Fall and P. S. Solomon, "Role of cereal secondary metabolites involved in mediating the outcome of plantpathogen interactions," Metabolites, vol. 1, no. 1, pp. 64-78, 2011.

[114] N. Nejat, J. Rookes, N. L. Mantri, and D. M. Cahill, "Plantpathogen interactions: toward development of next-generation disease-resistant plants," Critical Reviews in Biotechnology, vol. 37, no. 2, pp. 229-237, 2016.

[115] F. Katagiri and K. Tsuda, "Understanding the plant immune system," Molecular Plant-Microbe Interactions, vol. 23, no. 12, pp. 1531-1536, 2010.

[116] R. Gupta, S. E. Lee, G. K. Agrawal et al., "Understanding the plant-pathogen interactions in the context of proteomicsgenerated apoplastic proteins inventory," Frontiers in Plant Science, vol. 6, p. 352, 2015.

[117] S. Hulsmans, M. Rodriguez, B. De Coninck, and F. Rolland, "The SnRK1 energy sensor in plant biotic interactions," Trends in Plant Science, vol. 21, no. 8, pp. 648-661, 2016.

[118] P. N. Dodds and J. P. Rathjen, "Plant immunity: towards an integrated view of plant-pathogen interactions," Nature Reviews Genetics, vol. 11, no. 8, pp. 539-548, 2010.

[119] R. Oliva, J. Win, S. Raffaele et al., "Recent developments in effector biology of filamentous plant pathogens," Cellular Microbiology, vol. 12, no. 6, pp. 705-715, 2010.

[120] H. Li and Z. Zhang, "Systems understanding of plant-pathogen interactions through genome-wide protein\&ndash;protein interaction networks," Frontiers of Agricultural Science and Engineering, vol. 3, no. 2, pp. 102-112, 2016. 